\title{
Kinetics of Antibody Titers and Degree of Protection in Indian Major Carps, Catla (Catla catla) and Rohu (Labeo rohita) to Aeromonas hydrophila Antigen
}

\author{
Binod Kalita ${ }^{1}$, Hemanta Pokhrel ${ }^{1 *}$, Inam Akhtar Hussain ${ }^{1}$ and C.V. Mohan ${ }^{2}$ \\ ${ }^{1}$ College of Fisheries, Raha, Nagaon, Assam, India \\ ${ }^{2}$ World Fish, NACA, India \\ *Corresponding author
}

\begin{abstract}
A B S T R A C T
The kinetics of antibody titers and degree of protection in Indian major carps, catla (Catla catla) and rohu (Labeo rohita) against Aeromonas hydrophila antigen were studied in details at four different age groups of 120, 150, 210 and 270 days old. The first injection

Keywords

Indian major carps,

Kinetics, Antibody titer, Antigen

Article Info

Accepted:

10 August 2018

Available Online:

10 September 2018 (i.m) was given with $0.5 \mathrm{ml}$ of $10^{8}$ cells/fish of $A$. hydrophila antigen. The second injection was given on 20 days after the first injection with same dose. The peak antibody titer was observed on day 14 after first injection and on day 7 after second injection in all the age groups of both the species. Higher age groups of fish produced higher level of antibody titers after first as well as second injection. Antibody levels were found to decrease on day 21 after first injection and on day 14 after second injection. The secondary antibody titers were higher to that of antibody primary titers produced in all age groups and was significant $(p<0.05)$. The level of antibody titers also increased with age within the species. Catla showed higher level of antibody titers compared to rohu in all the age groups after first and second injection. A considerable amount of protection was recorded on day 14 after first injection. High degree of protection was recorded on day 7 after second injection in all the age groups of fish in both the species. The protection levels were higher in older age groups after first as well as second injection and was significant $(p<0.05)$. Catla showed higher degree of protection compared to rohu in all the age groups.
\end{abstract}

\section{Introduction}

Immune response has been studied in many fish species to a variety of antigens and recent investigations have shown that teleosts have the immunological capacity to respond to a variety of antigens (Smith et al., 1967; Kidder et al., 1973; Lamers and van Muiswinkel, 1985a; Grondel et al., 1987; Karunasagar et al., 1991; Azad et al., 1999; Kalita et al.,
2006). Aeromonas hydrophila is a gramnegative bacterium, ubiquitous and heterogonous organism that produces disease known as motile aeromonad septicaemia (MAS) in fish under stress condition or in concert with infection by other pathogens. Protection in rainbow trout immunized with heat killed $A$. hydrophila cells against the homologous strain was reported upto 7 months after vaccination (Post, 1966). Lamers et al., 
(1985a) studied the humoral immune response and memory formation in carp (Cyprinus carpio) against formalin killed A. hydrophila and maximum antibody titer remained upto day 20. Heat killed bacterin of A. hydrophila induced higher antibody levels in carp (Cyprinus carpio) than formalin killed bacterin (Lamers and De Hass, 1983). Karunasagar et al., (1991) reported very high antibody titers in catla followed by mrigal and rohu immunized by different routes against a haemolysin negative mutant $A$. hydrophila. The nature of antibodies produced in trout after injection, immersion and oral vaccination of live cells of A. hydrophila was studied (Loghothetis and Austin, 1994). The kinetics of the humoral response in bony fishes had studied in detail (Sailendri and Muthukkaruppan, 1975; Rijkers, 1982). Depending on the type of antigen and fish species, decrease in antibody titer may be fast or slow (Ellis, 1989) and also memory has been demonstrated in fish for cellular and humoral immune reactions (Botham et al., 1980; Rizkars et al., 1980a, Rizkers, 1982). Establishment of memory in carp took longer time than in mammals and remained for 8-12 months after primary stimulation (Lamers et $a l ., 1985 \mathrm{c})$. The dependence of temperature on the immune response of poikilothermic vertebrates has been studied and reviewed (Rijkers et al., 1980b). Thus, the present study was carried out to evaluate the kinetics of antibody titers and protective response against A. hydrophila antigen at different age groups of the two species of Indian major carps, catla (Catla catla) and rohu (Labeo rohita).

\section{Materials and Methods}

Fish: Hatchlings of 4 days old of Indian major carps, catla (Catla catla) and rohu (Labeo rohita) belonging to a particular brood stock were procured from the State Fish Seed Farm, BR project, Karnataka, India. Fishes were maintained in fish pond at college fish farm. Fish were fed twice daily and were segregated a specific interval and reared in same condition for 365 days. Four age groups (120, 150,210 and 270 days old) of each species were considered for experimental purpose and average length and weight of different age groups are given in the Table 1.

Antigen: Virulent strain of A. hydrophila isolated from EUS affected Sillago sihama was used as antigen. The bacterium was grown in tryptose soya broth (TSB, Himedia, India) for $24 \mathrm{hrs}$ at room temperature to a cell density of approximately $10^{9}$ cells $/ \mathrm{ml}$. Cells were harvested by centrifugation for 10 minutes at 10, $000 \mathrm{rpm}$ and washed three times in sterile phosphate buffered saline (PBS) and heat inactivated at $60^{\circ} \mathrm{C}$ for $1 \mathrm{hr}$ in water bath. Inactivation was confirmed by spread plate count method. Antigen was kept at $4^{\circ} \mathrm{C}$ until used.

Immunization: 125 numbers of catla and rohu from each age group were acclimatized for 7 days in cement cisterns. After acclimatization, fishes were injected (i.m) with $0.1 \mathrm{ml}$ of $10^{8}$ cells/fish of $A$. hydrophila antigen and control group of fish received $0.1 \mathrm{ml} /$ fish of phosphate buffer saline. The second injection was given 20 days after the first injection with same dose.

Antibody titers: Blood was collected individually from 5 numbers of fishes through caudal puncture at weekly intervals upto 3 weeks after first and second injection for estimating the antibody titers. Collected blood was stored overnight at $4^{\circ} \mathrm{C}$. Serum was separated by centrifugation at $6000 \mathrm{rpm}$ for 10 min, inactivated at $55^{\circ} \mathrm{C}$ for $30 \mathrm{~min}$ in a thermostat water bath. Doubling dilutions of the serum in sterile phosphate buffered saline (PBS pH 7.2) were taken in ' $U$ ' bottom microtiter plate. Equal volume of heat inactivated suspension $\left(10^{9}\right.$ cells $\left./ \mathrm{ml}\right)$ of $A$. hydrophila was added with serum in each well. The plates were incubated for overnight at $4^{\circ} \mathrm{C}$. The last dilution of the serum showing clear 
agglutination was taken as the titer and expressed in $\log _{2}$ values (Sundick and Rose, 1980). Challenge: Immunized and control fish were challenged with a fresh culture of $A$. hydrophila grown on TSB for $24 \mathrm{hrs}$ at room temperature. Ten numbers of fish in duplicate from immunized and control groups were challenged by injection (i.m) of $0.5 \mathrm{ml}\left(10^{6}\right.$ cells/fish) of $A$. hydrophila at 14 and 21 days after first and also at 7, 14 and 21 days after second injection. The mortality was recorded daily upto 8 days post-challenge and relative percent survival (RPS) was analyzed as described by Amend (1981).

\section{Results and Discussion}

The kinetics of the primary and secondary antibody titers to $A$. hydrophila antigen at different age groups of catla (Catla catla) and rohu (Labeo rohita) is given (Table 2 and 3). Catla and rohu produced antibody titers at all age groups against the $A$. hydrophila antigen. The peak antibody levels recorded on 14 days after first injection were $8.25 \pm 0.25 ; 8.5 \pm 0.25$; $8.75 \pm 0.25$ and $9.16 \pm 0.30$ for $120,150,210$ and 270 day old groups of catla respectively. While, in case of rohu, the peak antibody titers recorded on 14 days following first injection against $A$. hydrophila antigen were $7.40 \pm 0.24$, $7.42 \pm 0.20,8.00 \pm 0.17$ and $8.89 \pm 0.11$ for 120 , 150,210 and 270 day - old groups of rohu respectively. The antibody levels were found to decrease 21 days after first injection in both catla and rohu. Higher age groups of fish recorded higher level of antibody titers with increase in age of the fish. The peak primary antibody titers increased with both the species are given (Table 2 and 3). The peak antibody titers produced in higher age groups were significant $(p<0.05)$ compared to the lower age groups within the species. However catla showed higher level of primary and secondary antibody titers than rohu in all age groups. Similar observation was reported by Ellis (1989) that the antibody producing cells reached their peak numbers in 10-15 days and titers reached their maximum after 20-30 days. In common carp, Lamers et al., (1985b) reported that the peak antibody titers reached on day 20 after primary (i.m) injection with high dose $10^{9}$ cells/fish with $A$. hydrophila antigen. The peak primary antibody titer in the present study was observed little earlier on day 14 after first injection with dose of $10^{8}$ cells/fish, which might have influenced by the higher ambient temperature during the experiment. Moreover, it is well known that in all poikilothermic vertebrates, the ambient temperature influences the kinetics of metabolic process.

Fishes were injected with heat killed $A$. hydrophila antigen by i.m injection and could produce high level of antibody titers after first injection in this study. Similar observations were made earlier by Lamers and De Hass (1983) in common carp that heat killed $A$. hydrophila cells were more immunogenic than the formalin killed cells. While, Ingram and Alexander (1976) had also shown in rainbow trout and Harris (1973) in dace, Leuciscus leuciscus reported that i.m. injection was more effective for induction of primary responses than i.p. injection.

Table.1 Average length-weight of Indian major carps (Catla catla and Labeo rohita) in different age groups

\begin{tabular}{|l|l|l|l|l|}
\hline \multicolumn{1}{|c|}{ Days } & \multicolumn{2}{|c|}{ Catla catla } & \multicolumn{2}{c|}{ Labeo rohita } \\
\hline & Length $(\mathrm{cm} \pm$ S.E. $)$ & Weight $(\mathrm{g} \pm$ S.E. $)$ & Length $(\mathrm{cm} \pm$ S.E. $)$ & Weight $(\mathrm{g} \pm$ S.E. $)$ \\
\hline 120 & $12.80 \pm 1.22$ & $24.42 \pm 0.81$ & $13.10 \pm 0.75$ & $21.12 \pm 0.42$ \\
\hline 150 & $14.80 \pm 1.22$ & $43.10 \pm 1.86$ & $14.50 \pm 2.33$ & $35.52 \pm 0.37$ \\
\hline 210 & $19.40 \pm 1.70$ & $83.80 \pm 1.46$ & $17.70 \pm 1.22$ & $71.50 \pm 0.65$ \\
\hline 270 & $23.40 \pm 1.87$ & $163.00 \pm 3.74$ & $21.62 \pm 3.75$ & $138.40 \pm 3.23$ \\
\hline
\end{tabular}


Table.2 Antibody titers $\left(\log _{2}\right)$ in different age groups of Catla catla after injection immunization with A. hydrophila antigen

\begin{tabular}{|c|c|c|c|c|c|c|c|}
\hline \multirow{3}{*}{ Age (days) } & \multirow{3}{*}{ Test group } & \multicolumn{6}{|c|}{ Antibody titer $\left(\log _{2}\right)$} \\
\hline & & \multicolumn{3}{|c|}{ Days after first injection } & \multicolumn{3}{|c|}{ Days after second injection } \\
\hline & & 7 & 14 & 21 & 7 & 14 & 21 \\
\hline 120 & $\begin{array}{c}\text { I } \\
\text { Cont. }\end{array}$ & $\begin{array}{l}6.25 \pm 0.25 \\
0.40 \pm 0.22\end{array}$ & $\begin{array}{l}8.25 \pm 0.25 \\
0.40 \pm 0.24\end{array}$ & $\begin{array}{l}6.25 \pm 0.25 \\
0.60 \pm 0.36\end{array}$ & $\begin{array}{l}9.00 \pm 0.31 \\
0.50 \pm 0.34\end{array}$ & $\begin{array}{l}8.60 \pm 0.33 \\
0.40 \pm 0.24\end{array}$ & $\begin{array}{l}6.66 \pm 0.33 \\
0.40 \pm 0.24\end{array}$ \\
\hline 150 & $\begin{array}{c}\text { I } \\
\text { Cont. }\end{array}$ & $\begin{array}{l}6.25 \pm 0.22 \\
0.62 \pm 0.37\end{array}$ & $\begin{array}{l}8.50 \pm 0.22 \\
0.50 \pm 0.25\end{array}$ & $\begin{array}{l}7.00 \pm 0.57 \\
0.66 \pm 0.49\end{array}$ & $\begin{array}{l}9.25 \pm 0.25 \\
0.33 \pm 0.23\end{array}$ & $\begin{array}{l}8.80 \pm 0.20 \\
0.40 \pm 0.24\end{array}$ & $\begin{array}{l}7.25 \pm 0.22 \\
0.50 \pm 0.50\end{array}$ \\
\hline 210 & $\begin{array}{c}\text { I } \\
\text { Cont. }\end{array}$ & $\begin{array}{l}7.25 \pm 0.25 \\
0.60 \pm 0.36\end{array}$ & $\begin{array}{l}8.75 \pm 0.25 \\
0.40 \pm 0.24\end{array}$ & $\begin{array}{l}7.42 \pm 0.20 \\
0.50 \pm 0.34\end{array}$ & $\begin{array}{l}9.66 \pm 0.33 \\
0.83 \pm 0.40\end{array}$ & $\begin{array}{l}9.60 \pm 0.24 \\
0.60 \pm 0.36\end{array}$ & $\begin{array}{l}7.80 \pm 0.37 \\
0.50 \pm 0.26\end{array}$ \\
\hline 270 & $\begin{array}{c}\text { I } \\
\text { Cont. }\end{array}$ & $\begin{array}{l}8.33 \pm 0.21 \\
0.60 \pm 0.22\end{array}$ & $\begin{array}{l}9.16 \pm 0.30 \\
0.71 \pm 0.18\end{array}$ & $\begin{array}{l}8.80 \pm 0.20 \\
0.71 \pm 0.35\end{array}$ & $\begin{array}{l}10.50 \pm 0.22 \\
0.75 \pm 0.41\end{array}$ & $\begin{array}{l}9.75 \pm 0.25 \\
0.50 \pm 0.31\end{array}$ & $\begin{array}{l}8.25 \pm 0.25 \\
0.40 \pm 0.22\end{array}$ \\
\hline
\end{tabular}

*Second injection given on day 21 after first injection

I= Immunized 
Table.3 Antibody titers $\left(\log _{2}\right)$ in different age groups of Labeo rohita after injection immunization with A. hydrophila antigen

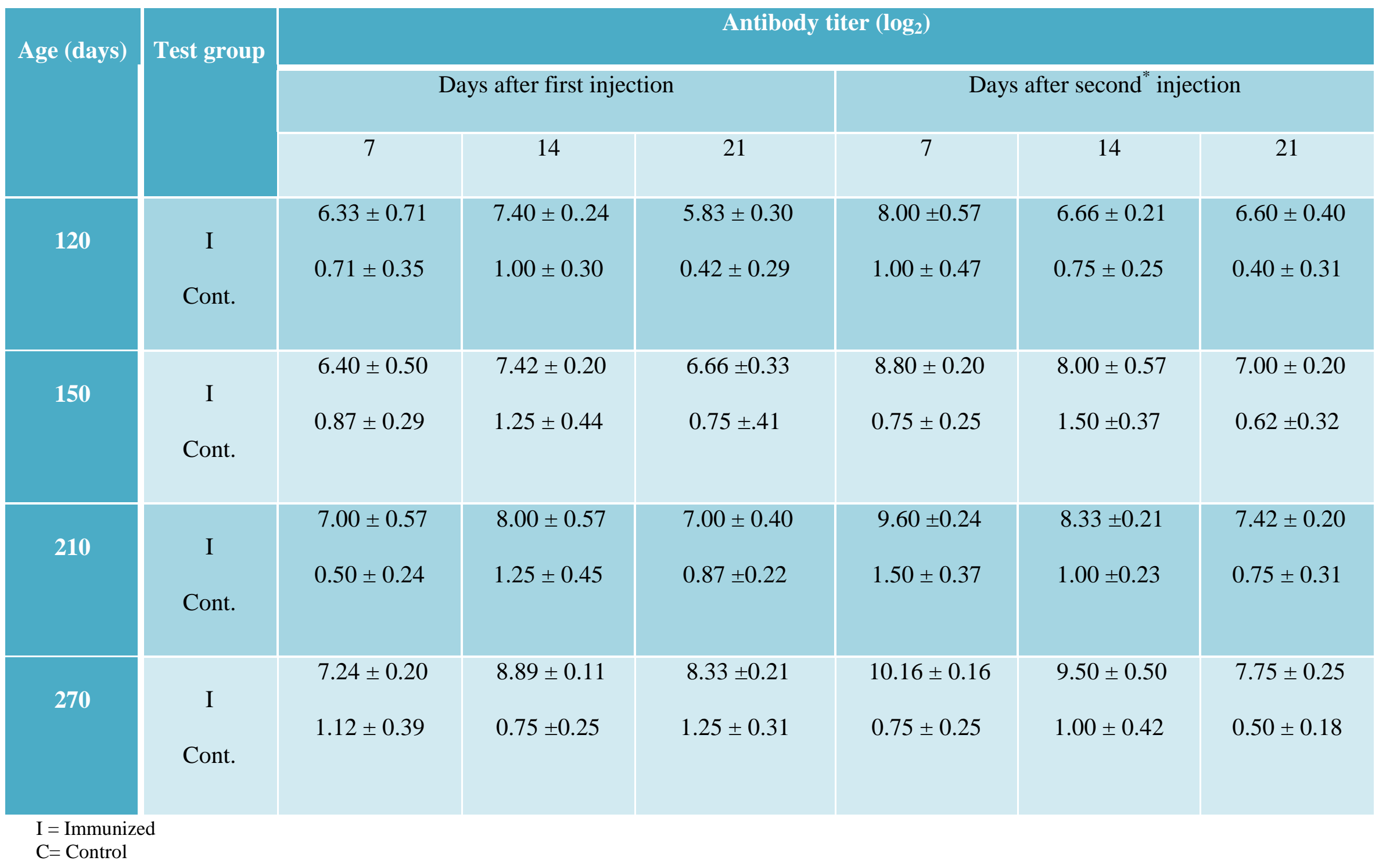


Table.4 Comparison of protective response (RPS) in injection immunized Catla catla and Labeo rohita in different age groups upon homologous challenge $\left(10^{6} \mathrm{CFU} /\right.$ fish i.m) with A. hydrophila

\begin{tabular}{|c|c|c|c|c|c|c|c|}
\hline \multirow{3}{*}{ Species } & \multirow{3}{*}{$\begin{array}{l}\text { Age group } \\
\text { (days) }\end{array}$} & \multicolumn{6}{|c|}{ Protective response as RPS } \\
\hline & & \multicolumn{3}{|c|}{ Days after first injection } & \multicolumn{3}{|c|}{ Days after second injection } \\
\hline & & 7 & 14 & 21 & 7 & 14 & 21 \\
\hline \multirow{4}{*}{ Catla catla } & 120 & ND & 46.67 & 37.50 & 72.22 & 50.00 & 41.17 \\
\hline & 150 & ND & 50.00 & 41.17 & 75.00 & 56.25 & 52.94 \\
\hline & 210 & ND & 57.14 & 46.67 & 78.57 & 62.50 & 60.00 \\
\hline & 270 & ND & 60.00 & 56.25 & 81.25 & 70.59 & 64.70 \\
\hline \multirow{4}{*}{$\begin{array}{l}\text { Labeo } \\
\text { rohita }\end{array}$} & 120 & ND & 38.46 & 28.57 & 64.28 & 46.15 & 38.46 \\
\hline & 150 & ND & 46.15 & 35.29 & 66.66 & 53.84 & 41.66 \\
\hline & 210 & ND & 53.84 & 42.86 & 73.33 & 57.14 & 46.67 \\
\hline & 270 & ND & 58.33 & 46.67 & 76.92 & 66.66 & 58.38 \\
\hline
\end{tabular}


The peak antibody titers in catla measured on 7 days after second injection was higher in all age groups compared to the peak primary antibody titers on 14 days after the first injection. The antibody titers recorded were $9.00 \pm 0.54, \quad 9.50 \pm 0.50, \quad 9.66 \pm 0.33$ and $10.50 \pm 0.22$ for $120,150,210$ and 270 days old catla respectively. While, the peak antibody titers in rohu measured on 7 days after second injection was higher in all age groups compared to the peak primary antibody titers measured on 14 days after the first injection.

The antibody titers recorded were $8.00 \pm 0.57$, $8.80 \pm 0.20,9.60 \pm 0.24$ and $10.16 \pm 0.16$ for 120 , 150, 210 and 270 day-old respectively (Table 2 and 3). The levels of antibody titers were found to decrease after 14 days of second injection. The secondary antibody titers in rohu recorded 7 days after second injection were higher in all age groups. Higher age groups showed higher levels of antibody titers within the species and the peak secondary antibody titers were significant $(p<0.05)$ compared to the peak primary antibody titers obtained in catla and rohu.

The secondary antibody titers were not significantly different between the age groups of the species. However, enhanced level of secondary antibody titers were observed with increase in age/size of the fish, which clearly indicates that size/age of the fish has a prominent effect on the secondary immune response. However, catla showed higher level of primary and secondary antibody titers than rohu in all age groups. Karunasagar et al., (1991) reported that immunized fingerlings of the three species of Indian major carps against A. hydrophila via three different routes, catla showed the maximum antibody titers followed by mrigala and rohu. However, Azad et al., (1999) documented that responses of catla and rohu showed similar trends with respect to antibody titers against A. hydrophila with different doses of oral vaccination.

Details of protective response (RPS) following challenge on 14 and 21 days after first injection and 7, 14 and 21 days after second injection in four different age groups are given (Table 4). Protective response obtained on day 14 was higher in all the age groups after first injection. The maximum protection $(60.00 \%)$ was recorded for 270 day- old age group and minimum protection was $(46.67 \%)$ for 120 day-old group. Higher protection level was obtained on day 7 after second injection in all the age groups. The maximum protection $(81.25 \%)$ was recorded for the 270 day-old age group and minimum protection $(72.22 \%)$ in 120 day-old age group of catla. In case of rohu, higher levels of protective response were recorded in all age groups on day 14 after first injection. The maximum protection $(58.33 \%)$ was found for 270 day-old age and minimum protection (38.46\%) for 120 day-old age groups. Higher protection level was recorded in all the age groups on day 7 after second injection. The maximum $(72.22 \%)$ and minimum $(64.78 \%)$ protection were found for 270 day and 120 day-old age groups of rohu respectively.

The protection level was higher in older age groups of catla and rohu after first as well as after second injection. The protective response was significant $(\mathrm{p}<0.05)$ in both the species due to second injection and with the age of the species. Catla showed higher degree of protective response compared to rohu in all the age groups. Earlier reports made by Khalifa and Post (1976) reported that $100 \%$ protection was achieved in rainbow trout at antibody titer of 1:32. The present study indicates that the enhanced antibody titers with increase in age/size might have affect in protective response in both the species. Karunasagar et al., (1991) showed positive correlation of protection with the level of antibodies in all the three species of 
Indian major carps, where a particular age group of fingerlings was used and reported that maximum protection was recorded in catla and lowest in rohu. However, catla showed higher level of protection in all the age groups than rohu after first as well as second injection in this study, which might be due to specific growth rate and innate mechanism of the species.

\section{References}

Amend DF (1981). Potency testing of fish vaccines. Dev. Biol. Standards, 49: 447454.

Azad IS, Shankar KM, Mohan CV, Kalita B (1999). Bioflim vaccine of Aeromonas hydrophila -Standardization of dose and duration for oral vaccination of carps, Fish and Shellfish Immunology, 9: 519528.

Botham JW, Grace MF, Manning MJ (1980). Ontogeny of first set and second set alloimmune reactivity in fishes. In: Manning, M.J. (Ed.). Phylogeny of Immunological memory. Amsterdam. Elsevier/North Holland. Pp. 83-92.

Ellis AE (1989). The immunology of teleosts. In: Roberts, R.J., (Ed.). Fish Pathology, Bailleire Tindall, London, pp. 135-139.

Grondel JL, Nouws JFM, van Muiswinkel WB (1987). The influence of antibiotics on the immune system: immunepharmokineunasagtic investigations on the primary anti SRBC response in carp, Cyprinus carpio L. after oxytetracycline injection. J Fish Diseases. 10: 5-45.

Harris JE (1973). The immune response of dace Leuciscus leuciscus to injected antigenic materials. J. Fish. Biol., 5: 261-276.

Ingram G, Alexander JB (1976). The immune response of brown trout (Salmo trutta L.) to injection with soluble antigens. Acta. Biol. Med. Germ., 35: 1561-1570.
Kalita B, Mohan CV, Shankar KM, Azad IS (2006). Humoral and protective response of Indian major carps to immersion vaccination with Aeromonas hydrophila. J Indian Fish Assoc 33: 161-168.

Karunasagar I, Rosland G, Karnasagar I (1991) Immunological response of the Indian major carps to Aeromonas hydrophila vaccine. J Fish Diseases. 14: 413-417.

Khalifa K, Post G (1976). Immune response of advanced rainbow trout fry to Aeromonas liquefaciens. Prog. Fishcult., 38: 66-68.

Kidder GM, Ruben IN, Steven JM (1973). Cytodynamics and ontogeny of the immune response of Xenopus laevis against sheep erythrocytes. J Embryol Exp Morph 29: 7-85.

Lamers CHJ, De HAAS MJH, van Muiswinkel WB (1985c). The reaction of the immune system of fishes to vaccination: development of immunological memory in carp, Cyprinus carpio L. following direct immersion in Aeromonas hydrophila bacterin. J. Fish. Dis., 8: 253-262.

Lamers CHJ, van Muiswinkel WB (1985a). The fate of intraperitoneally inject carbon particles in cyprinid fish. Cell Tissue Res 42: 499-503.

Lamers CJH, De HAAS MJH (1983). The development of immunological memory in carp (Cyprinus carpio L.) to a bacterial antigen Dev. Comp. Immunol., 7: 713-714.

Lamers, CHJ, De Haas MJH, van Muiswinkel WB (1985b). Humoral response and memory formation in carp after injection of Aeromonas hydrophila bacterin Dev. Comp. Immunol, 9: 65-75.

Loghothetis PN, Austin B (1994). Immune response of rainbow trout (Onchorhynchus mykiss Walbaum) to 
Aeromonas hydrophila. Fish and Shellfish Immunology, 4(4): 239-254.

Post G (1966). Response of rainbow trout (Salmo gairdneri) to antigens of Aeromonas hydrophila. J. Fish. Res. Bd. Can., 23: 1487-1494

Rijkers GT (1982) Kinetics of humoral and cellular immune reactions in fish. Dev. Comp. Immunol., Suppl 2: 93-100.

Rijkers GT Teunissen AG Van Oosterom R, Van Muiswinkel WB (1980a) The immune system of cyprinid fish. The immunosuppressive effects of the antinbiotic oxytetracycline in carp (Cyprinus carpio L). Aquaculture, 19: 177-189.

Rijkers GT, Frederix-Walters EMH, van Muiswinkel WB (1980b) The immune system of cyprinid fish. The effect of antigen dose and route of administration on the development of immunological memory in carp (Cyprinus carpio). In: Manning, M.J., (Ed.). Phylogeny of Immunological Memory. Elsevier/North Holland Biomedical Press, Amsterdam, pp. 93-102.

Sailendri K, Muthukkaruppan VR (1975). Morphology of lymphoid organs in a cichlid teleost, Tilapia mossambica (Peters). J. Morph., 147: 109-283.

Smith AM, Potter M, Merchant EB (1967). Antibody-forming cells in the pronephros of the teleost, Lepomis macrochirus. J Immunol 99: 876-882.

Sundick RS, Rose NR (1980). Agglutination reaction. In: Rose, N.R. and Bagazzi, P.E. (Eds.). Methods in immunodiagnosis. John Wiley and Sons. Chichester, pp. 108-127.

\section{How to cite this article:}

Binod Kalita, Hemanta Pokhrel, Inam Akhtar Hussain and Mohan, C.V. 2018. Kinetics of Antibody Titers and Degree of Protection in Indian Major Carps, Catla (Catla catla) and Rohu (Labeo rohita) to Aeromonas hydrophila Antigen. Int.J.Curr.Microbiol.App.Sci. 7(09): 14611469. doi: https://doi.org/10.20546/ijcmas.2018.709.175 